\title{
Nutrition, Nurture and Nature
}

Differing conceptions of the countryside; examples from Scotland, Ireland and England

Alimentation, nourriture et nature : différentes conceptions en milieu rural; exemples en Écosse, Irlande et Angleterre

Helen Macbeth et Paul Collinson

\section{OpenEdition}

\section{Journals}

Édition électronique

URL : http://journals.openedition.org/ethnoecologie/935

DOI : 10.4000/ethnoecologie.935

ISSN : 2267-2419

\section{Éditeur}

Laboratoire Eco-anthropologie et Ethnobiologie

\section{Référence électronique}

Helen Macbeth et Paul Collinson, « Nutrition, Nurture and Nature », Revue d'ethnoécologie [En ligne], 2 | 2012, mis en ligne le 12 novembre 2013, consulté le 01 mai 2019. URL : http:// journals.openedition.org/ethnoecologie/935 ; DOI : 10.4000/ethnoecologie.935

Ce document a été généré automatiquement le 1 mai 2019.

Revue d'ethnoécologie est mis à disposition selon les termes de la licence Creative Commons Attribution - Pas d'Utilisation Commerciale - Pas de Modification 4.0 International. 


\title{
Nutrition, Nurture and Nature
}

\author{
Differing conceptions of the countryside; examples from Scotland, \\ Ireland and England
}

Alimentation, nourriture et nature : différentes conceptions en milieu rural ; exemples en Écosse, Irlande et Angleterre

Helen Macbeth et Paul Collinson

\section{Introduction}

1 The title of this chapter partly derives from Macbeth's (1989) criticism of so much in the arguments by biological and social scientists concerning the so-called 'Nature/Nurture debate', which for decades was a fruitless debate frequently involving incompatibility in terminology and poor understanding of genetic and non-genetic processes. The genetic processes included in such a concept of 'nature' can never exist without nurture, ... nor vice versa! They interact at every stage, are inseparable and can never be considered parts of a simple dichotomy.

2 However, some people do not comprehend that, in the narrow sense of that debate, 'nature' refers to genetic processes. Thanks to the flexibility of the English language, the word 'nature' popularly conjures up the idea of the natural biological environment - even the concept of the natural as opposed to the managed biological environment. With this interpretation, as Macbeth has argued elsewhere (2006), the phrase 'nature conservation' must be a contradiction in terms. Firstly, because it implies some form of management. Secondly, because a fundamental part of the ecology of all natural environments (even when managed!!) is change. Conservation, therefore, must be the antithesis of this, as it implies a deliberate attempt to impede change. In regard to biodiversity, then, attempts at 'nature conservation' lead to the question of what should be conserved and to the obverse of this - at the cost of what? The word, biodiversity, only implies diversity and does not impute any qualities to the variants, new or ancient, native or intrusive, in that diversity. 
3 A common example of so-called 'nature conservation' is the conservation of species native to an area (since some unspecified period of time!) at the cost of invading species, frequently with the ambition of "supporting biodiversity". Yet, a more critical approach to this should involve concepts of both time and place, for, in any one 'place', biodiversity is immediately increased while both the invading species and the threatened species coexist. At a later time, in that place, the threatened species might disappear, and that might or might not mean its extinction worldwide, or both species might continue to exist either in balanced selection or in separate levels of the same environment. So, it seems essential that one should consider at what scales of time and place one is considering any ambition for biodiversity.

Returning to the word, nurture in the title, a very significant part of nurture for any species is nutrition, and so food. Although our paper builds up to a conclusion about the provision of food, our arguments will emanate from short ethnographic descriptions of some contrasting conceptions of the countryside, its environment, and debates about its use. This includes options such as production of food, leisure facilities, recreation activities, scenic views and, yes, nature conservation. Each of these might be considered as providing an asset, even an economic asset, to the area, but the options regularly compete for the same geographic space. So, stakeholders may well become embroiled in fierce struggles to support their preferred option, and in their opposing arguments they may each claim that their option supports biodiversity. Why the word, biodiversity, should figure in their contrasting arguments partly depends on the interpretation of biodiversity. Both innovators and conservators can rationally use the word. As Budiansky argued (1995), there have been many different perspectives on this in the academic disciplines of ecology, environmental biology, etc. In fact, Budiansky's book, Nature's Keepers: the new science of nature management, is strongly recommended to anyone struggling with concepts of biodiversity and nature.

So, to stress the point: it is that range of interpretations which sometimes allows both opposing sides in a land-use debate to claim that their objectives encourage biodiversity and are environmentally beneficial. Thus, is it such a startling statement to maintain that genetic modification of organisms (initially at least) increases biodiversity? Oh! Is this not what many mean by biodiversity? Please remember that it is in the context of crops, feed and food that the developments in genetically modified organisms (GMO) are usually defended, and the aim of genetic modification is to create new variants. So, although much of the contention for biodiversity has been aimed at conservation of native or rare species and not at innovation of new varieties, both or either might promote biodiversity.

In this chapter we shall relate these issues to differing conceptions of the countryside and debates about the use of land in three separate areas, one in Scotland, one in Ireland and one in England, and then draw the strands together in the conclusion. An aspect which stresses the importance of time in this debate is that these sections were written for a conference in 2008 and here are only briefly updated in 2013.

\section{The new national parks in Scotland : prior concerns and contentions}

7 The first of these ethnographic examples regards the inauguration of the first two national parks in Scotland in 2002 and 2003, following Scottish devolution and 
inauguration of the new Scottish Parliament, which Macbeth has discussed in greater detail elsewhere (2007).

Photo 1 Wild beauty of the mountains and lochs of Scotland

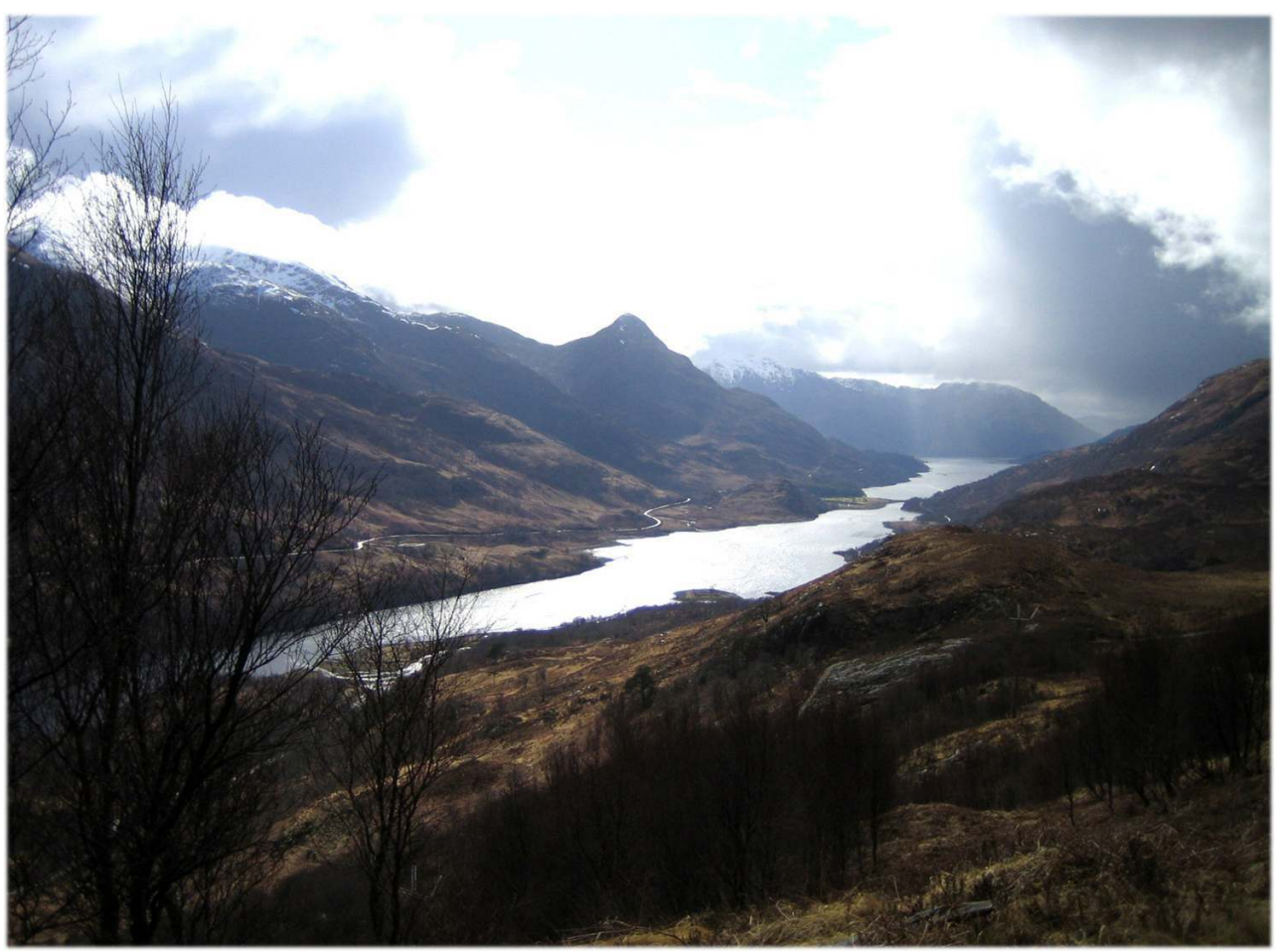

CHELEN MACBETH AND PAUL COLLINSON

With the wild beauty of the mountains and lochs of Scotland (Photo 1), the development of national parks seemed by many to be long overdue. Setting up such national parks had been debated for half a century before the National Parks (Scotland) Act was passed by the Parliament of newly devolved Scotland in the summer of 2000 (Scottish Natural Heritage 2001a). However, differing ambitions for the characteristics of these parks caused considerable controversy, shown even in the four aims eventually set up for the national parks, which are :

- to conserve and enhance the natural and cultural heritage of the area,

- to promote sustainable use of the natural resources of the area,

- to promote understanding and enjoyment (including enjoyment in the form of recreation) of the special qualities of the area by the public, and

- to promote sustainable economic and social development of the area's communities. (National Parks (Scotland) Act 2000)

Even a brief glance at these aims demonstrates some incompatibility of objectives. In fact, readers familiar with the regulation of national and natural parks in other countries may be very surprised by the insertion of 'cultural heritage', 'recreation' and 'social and economic development'. It is not in every country that concepts of national parks include these features ... and what do they do for biodiversity?

Macbeth's initial interest in studying local views about these new national parks had been related to wild food. There are good studies on the adverse effects on the nutrition of local inhabitants when areas in Africa (e.g. Adams and McShane 1996) and southern Europe (e.g. Cresta et al. 2000, González Turmo 1998) became designated as protected natural areas. The original research topic was whether this would be an issue for the local 
inhabitants of these new national parks in Scotland. Macbeth soon learned it was an irrelevance. For several generations the rights to shoot the deer and the game birds in the hills and to fish for the salmon in the rivers had been privately owned or rented, and these wild foods were simply not available to the general population, unless they were obtained through poaching, or donated by the landowners to their estate employees. What is more, very few locals retained any habit of gathering; there is a general mistrust of wild mushrooms, and berries are now bought in the supermarkets. Elderly folk were interviewed who remembered gathering berries, trapping rabbits ... and even poaching salmon, ... but they didn't think it worth bothering to do so nowadays. Even in the areas around the national parks supermarkets reign supreme - so, no! loss of access to the wild food just was not an issue for the locals in the designation of these new national parks in Scotland.

However, following Mars and Mars (2004) advice on fieldwork where an original topic turned out to be unsuitable, a different angle of research was pursued in regard to the attitudes to the proposed new parks. This research was based primarily on responses to a public consultation project (Scottish Natural Heritage 2001a, 2001b), and followed up by personal interviews. Responses demonstrated that some wanted their area to be inside the national park boundaries, while others wanted to be outside, for differing reasons, which we now discuss in relation to ideas about biodiversity.

In brief, in relation to the Cairngorms National Park many of the views expressed (Scottish Natural Heritage 2001b) concerned conservation in the wilderness areas, some identifying specific species of animal, bird, insect or plant, or even type of soil; it is not difficult to link these aspirations with the traditional concepts of biodiversity. Interestingly, people were divided as to whether national park status would hurt or help the preservation of the aspects that concerned them. In contrast, the responses (Scottish Natural Heritage 2001a) regarding the Loch Lomond and the Trossachs National Park (Photo 2) confounded our preconceived ideas about what people might want or fear from national park status. Very common were comments overtly hoping to encourage the socio-economic benefits of attracting tourists, i.e. the honey-pot attitude, entailing aspirations for more employment, more hotel and leisure facilities, more retail opportunities, and even for better roads and parking areas. Any sense of increasing biodiversity was simply lacking in such aspirations, although some other respondents were concerned with natural features and species. By 2013 both national parks are now well established and accepted, and the current heated debates are about setting up wind turbines, whether within the boundaries of the national parks or within sight of national park viewpoints. Once again participants in this debate use claims of environmental benefit on both sides of the argument. More national parks are now being considered in Scotland. 


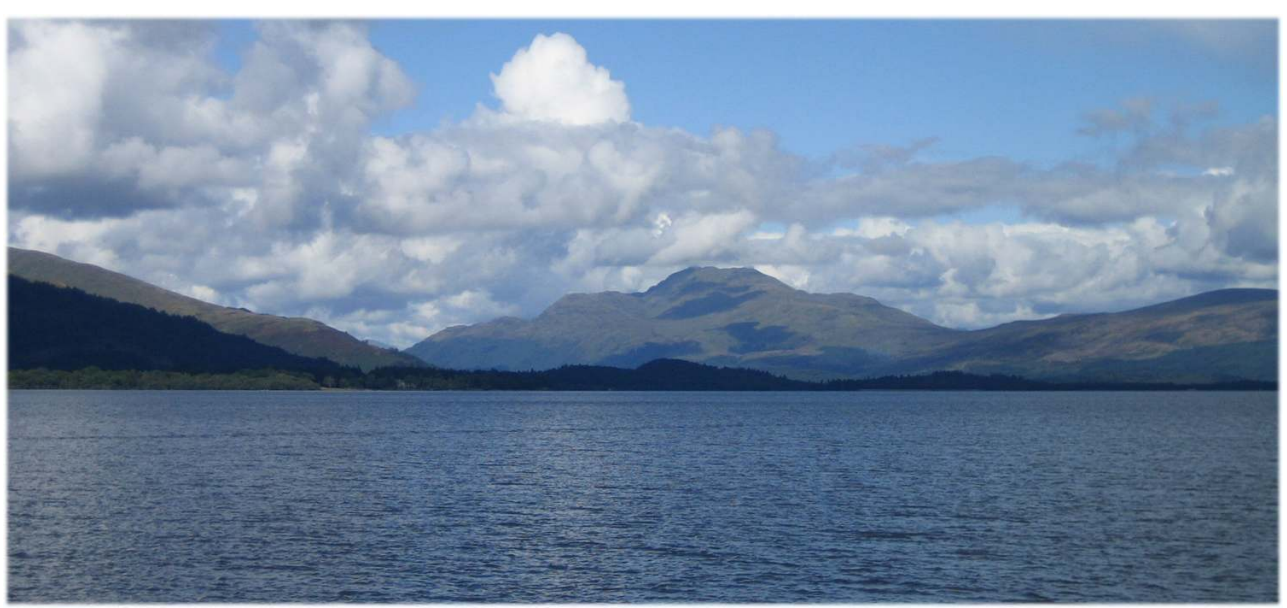

CHELEN MACBETH AND PAUL COLLINSON

13 It should be noted that in Britain the land within national parks is not owned by any governmental organisation, but by individual landowners, whether farmers, estate landowners, Forestry Commission, water boards, National Trust, etc. Although not owned by government, there would be a 'National Park Authority' for each park with a local legislative role, and a number of the responses in both reports were dedicated to who should sit on the councils of these national park authorities. One can understand why that would be a strongly debated issue.

In view of such private ownership of the land, it is important to remember that contemporary species managed by farmers are as much part of biodiversity as the threatened wild species in remote wildernesses, or even the carefully nurtured historical breeds, but this is seldom remarked upon in discussions of biodiversity. The lessons of the ecological and productive risks of the monogenetic crops of the so-called 'Green Revolution' have hopefully been learned. Encouraged by the Food and Agriculture Organization of the United Nations Organization, modern national and European legislation today provides standards of pedigree analysis and mating patterns and an interest in seed banks, with the aim of maintaining genetic polymorphisms. Thus, good agricultural practice should also foster biodiversity, while not all 'nature conservation' actually does. However, many small farms, and especially the hill farms, are now struggling financially, and many have already gone out of business, or are able to maintain their farms only by turning from full-time farming to ancillary occupations, including tourism. Regarding national park status, the farmers, personally interviewed by Macbeth, feared not only tourists trespassing on their farms, worrying sheep, etc., but they also dreaded the existence of another layer of bureaucracy with the new national park authorities. They already have to keep records for local district authorities, the national government and the European Community.

\section{Nature-nurture in Irish land-use}

Drawing on fieldwork conducted by Collinson in western Ireland since the late 1990s, our second example examines different notions of how people view the countryside, and how this relates to the way in which concepts such as conservation and biodiversity are 
interpreted in the locale. Debates surrounding the way the land should be used in Ireland often stem from deeper issues concerning the relationship between indigenes and outsiders, agricultural production and tourism, sustainability and consumerism, and the nature of Irish identity itself. They therefore go to the heart of the main theme of this paper : how nature is viewed and how nurture impacts upon this. (Photo 3)

Photo 3 Signs put up for tourists in the west of Ireland

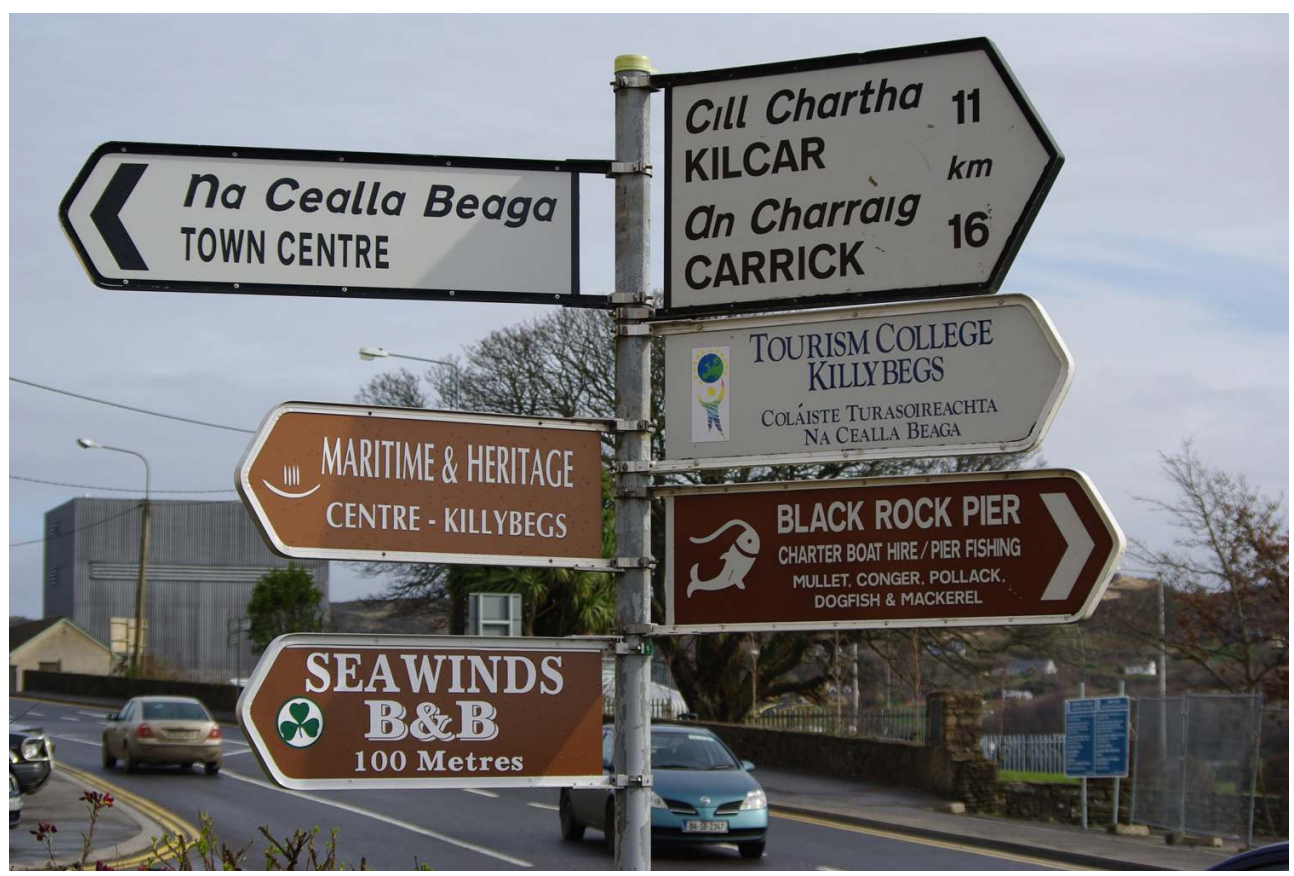

(C)HELEN MACBETH AND PAUL COLLINSON

As in the Highlands of Scotland, conceptions of the environment and how it should be used in western Ireland are highly contested. Blessed with a very rich and beautiful landscape, the Irish tourist industry has long marketed this part of Ireland as a pristine rural paradise, the perfect place for urban dwellers from other parts of the country and Europe to 'get away from it all'. Ecotourism and cultural tourism have become boom sectors, capitalising on an increasing demand for 'authenticity', 'tradition' and 'purity' in today's atomised, post-modern societies. However, an undoubted disjunction has emerged in recent years between the image of the area promoted in tourism campaigns and the reality on the ground. Those who visit the country today hoping actively to seek out what is promised in the tourist brochures may well return home disappointed.

A number of authors have noted the deleterious effects of the so-called Celtic Tiger phenomenon of the 1990s and early 2000s - when Ireland recorded some of the highest annual growth rates in the industrialised world - on the natural environment of the country (see, for example, McDonagh 2007, Kelly 2007, MacDonald and Nix 2006, Davies 2003, Wickham and Lohan 2000, Taylor 1998, Deegan and Dineen 1997, Dillon 1996). This has been caused partly by the diversification of land-use in rural areas, as the latter have moved away from their traditional role surrounding the growing of food. The effect has been more industrialisation, more pollution, more traffic, more noise, more people and, perhaps above all, more houses. Any visitor to rural Ireland today will be struck by the plethora of whitewashed houses dotting the landscape, many empty during the week as 
they are used as weekend bolt holes for wealthy urban dwellers, over 200,000 (one for every 20 people) in 2006, according to Boycott (2006). Most have been constructed during the last ten to fifteen years. And as the Celtic Tiger has turned out to be of the paper variety with Ireland's economic reversal since 2008, 'ghost' housing estates - newly-built homes where no-one lives - have become another prominent feature in the rural areas of the country. Ireland's excess housing stock was estimated to amount to 136,000 homes in 2009 , out of a population of approximately 4.3 million (DKM 2009). By way of illustration, a recent film set in western Ireland in the 1950s was eventually filmed in the Isle of Man, because the film crew found that the over-development of the Irish west coast was such that they were unable to find any suitable locations which could convincingly be used to portray Ireland as it was 50 years ago. And the 'Ring of Kerry', a famously picturesque circular drive in the south west of the country, is apparently grid-locked on a regular basis during the summer months, as a never-ending convoy of tourist buses attempts to negotiate its narrow roads and hair-pin bends. Many visitors today will also be struck by the apparently impoverished state of Irish agriculture - the vast tracts of unimproved pasture, the overgrown hedgerows, the carcasses of abandoned tractors or cars rusting in the fields, and the sheer amount of under-utilised land (Photo 4).

\section{Photo 4 Example of neglected and overgrown fiels in rural Ireland}

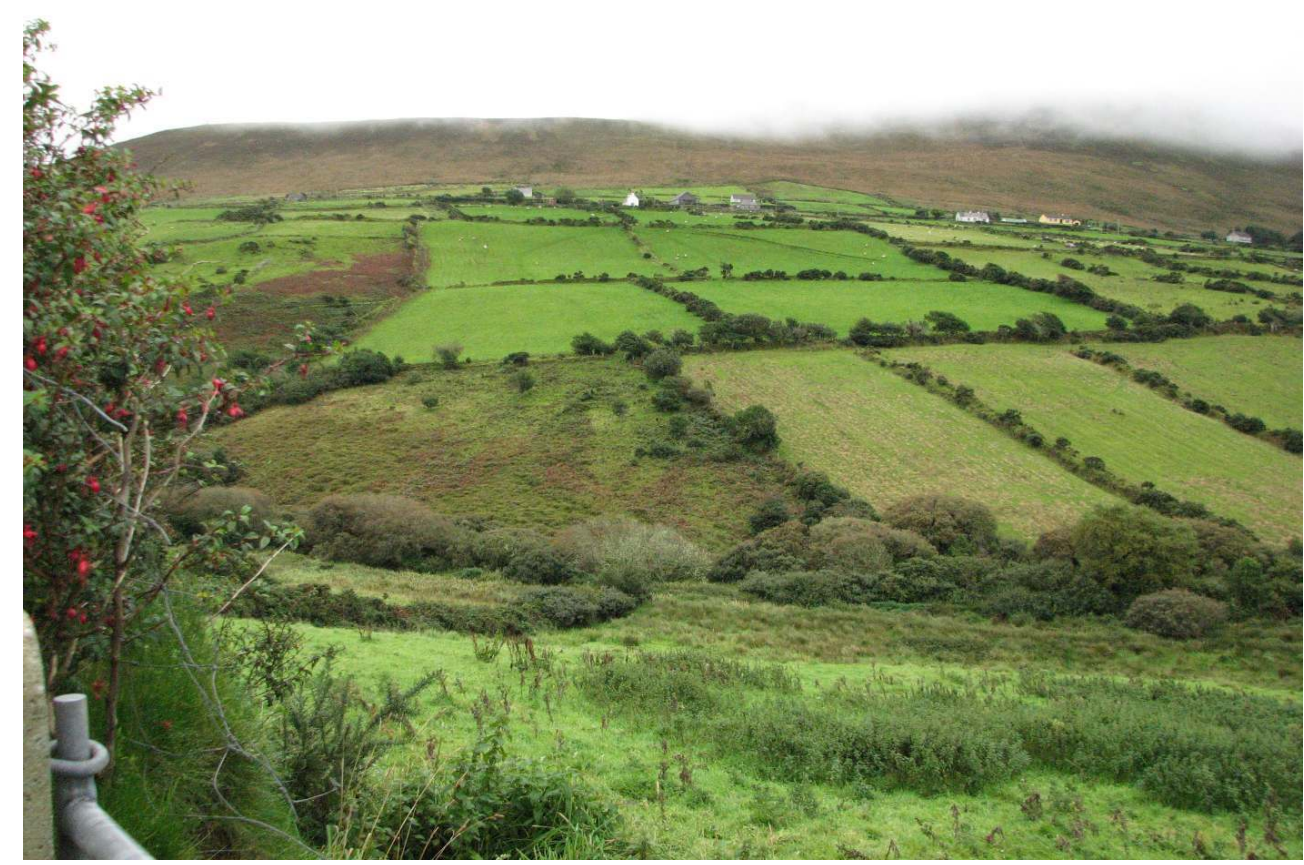

CHELEN MACBETH AND PAUL COLLINSON

18 It may be argued that the rather haphazard way in which the rural landscape is managed in Ireland stems from the ambiguous and complex attitude which the Irish population has towards the environment, ecology and biodiversity (c.f. McDonagh et al. 2009). As Ireland's National Biodiversity Plan acknowledges :

"In general, public appreciation of and knowledge of biodiversity is low. Harnessing local groups and ensuring local engagement with biodiversity issues would have a significant impact on conservation. There is a requirement for public education and 
awareness programmes that make biodiversity relevant to the public. This could be achieved by emphasising the economic costs of not conserving and highlighting the essential links between biodiversity and food production, nutrition and health." (Comhar $2008: 4$ )

19 Attitude surveys have found that involvement in environmental groups in Ireland is one of the lowest of those in all European countries (e.g. Kelly 2007, 2004, Motherway et al. 2003). The Irish government could also be accused of only legislating on sustainability and biodiversity because of a requirement to do so under EU regulations and laws (c.f. Tovey 2007, Coyle 1994).

These ambiguous attitudes stem in part from different conceptions of what the countryside is actually for, which themselves introduce wider questions concerning Irish national identity itself. The 'myth of the land' still has some power as a component of what it means to be Irish, with land always conceived of as a productive resource, a precious commodity to be preserved at all costs. The agricultural sector is still a very important one in Irish society and politics, viewed as intrinsic to the essence of Ireland and Irish identity. The horrors of the famine of the mid-nineteenth century live on in the country's historical memory, and continue to shape the population's perception of agriculture and development.

In western Ireland, land ownership remains a source of status, pride and ambition. During his fieldwork, Collinson came across many people who were working in professional occupations in the towns of the county - in different parts of the public service, as company managers, teachers, development workers, among others - who confessed to him with rather sheepish pride that they owned 'a little bit of land' in the rural areas of the county (Collinson 1999). Although much of this would have been inherited, his informants invariably talked about their land in almost reverential tones, as a source of prestige. People often talked about how they 'kept a few cows' on their land, and regarded it very much as insurance against a rainy day. Land is viewed as a saving of last resort, and it is likely that this attitude has only been reinforced by the recent global downturn and Ireland's own economic slump. However, this attitude stands at odds with the value of land in the county, and the inescapable fact that much of the land is uneconomic, with the agricultural sector supported almost entirely by subsidies from the EU. Farming in Donegal is largely marginal, and is focused around sheep and cattlerearing, with some staple crops such as wheat and maize grown in the valley floors.

Since 1990, the EU has been attempting to diversify economic activities in marginal rural areas of Europe. Many development programmes and projects have been established in Ireland during the past two decades, and a plethora of local community groups have sprung up to spend the EU's money. The people involved in these organisations are, in the main, more educated, relatively better-off and younger than the traditional farming community. They also tend to be female, and are often outsiders to the county (Collinson 2005). Most importantly, they have different ideas from the traditional farming community about managing the rural landscape; some even have focused on growing innovative crops, such as hemp, others on rearing exotic animals, such as llamas, thereby of course increasing biodiversity.

One such environmental group, based in the northern county of Donegal, is a case in point. Set up in the 1990s, the group is concerned primarily with promoting and improving the natural environment in the area. It has published brochures, designed and run marketing campaigns and created a network of walking trails in conjunction with the 
county council. Most of the group are outsiders to the area, and share a common set of concerns which distinguish them from many of those who were born and raised in the area. They are keen on growing their own food rather than buying it from supermarkets (where, as in Scotland, most people in Donegal now shop), using locally-owned businesses rather than multinational chains, buying environmentally-friendly products where possible, and promoting sustainable livelihoods. However, the group's activities have met with a great deal of resistance from others in the local population. This stems from different notions of how the land should be used, and is very much a product of the incomer / outsider dichotomy mentioned earlier. Members of the group do not believe that the indigenous population really care about the environment at all :

"You could plant an entire hillside with trees and no-one [in the local village] would bat an eyelid. They don't realise that the acid that comes off them will pollute all the brooks around here. There's a plantation down the road owned by some guy from Leitrim. He's never even visited the place, just bought it as an investment. When the trees are harvested, they'll ship all the timber over to mills in the north and destroy all the roads on the way in the process. I wouldn't mind if there were mills round here that were creating jobs for local people, but there isn't. The guy'll get $£ 50$ a tonne for the wood, which will bring him a fortune. People round here should be campaigning against this sort of thing, but they couldn't give a damn." (Informant's personal communication 1997)

A possible reason for the general unwillingness of the 'indigenous population' (itself a rather imprecise term) to become involved in the environmental / conservation movement in Ireland is its origins in the colonial era, when it was promoted by outsiders with strong ties to or representing British organisations (Leonard $2008: 21$ ).

To summarise: the traditional conception of the Irish rural landscape is one geared around the growing of food. This has changed in recent years under encouragement from the EU. Younger people and outsiders involved in environmental development are interested either in preserving a relic way of life in rural areas or introducing new forms of agriculture. The farming community, although having an ambiguous relationship with the environment, views the countryside's purpose to be the production of traditional foods - meat, basic cereals, potatoes etc. This tends to be reflected in the view of the majority of the local population as well, particularly the older generation. In terms of the promotion of biodiversity and sustainable development, neither side - in what has been characterised evocatively by Boyle (2002) as a 'culture war over transformed nature' - has the upper hand. Farmers claim they preserve the landscape for future generations, but most of their activities are uneconomic. Local development groups and the EU say that rural livelihoods must be diversified - but such diversification has altered the landscape in rural Ireland to the detriment of its value as a marketable commodity. Promoting tourism is all very well, but one needs something to promote.

\section{'Ecotowns' in southern England}

The third ethnographic description of contested countryside concerns a contemporary situation in rural southern England. In 2008, the then UK Government stated its intention to create some totally new 'ecotowns' in southern England, and thereafter had spent considerable resources in trying to find sites for such ecotowns. However, most of the proposed sites were rural land, and with a couple of exceptions, had caused great antagonism and outcry from those fighting the destruction of green spaces for increased 
concrete and tarmac. For a long time that Labour government had been trying to increase the number of houses in southern England, yet development planning is not in the hands of national government but of local government, with councillors who generally do not want their rural landscape turned suburban. While it is of course rather more complicated, that is where the fundamental tensions lie and concepts of biodiversity are extremely relevant to the debates. An underlying problem is that culturally the British generally have aspirations for a house with garden, and not an urban apartment. Finding land space for this in rural southern England is an ongoing difficulty. Then someone in Government came up with the idea of calling some new housing developments 'ecotowns' , thereby hoping to capture the imagination for something ecologically desirable, supported by the ambition to build homes with low or nil. carbon emissions. Yet, the sites chosen were in rural locations. This is presumably because the ecologically needed reconstruction of old energy-inefficient industrial land and housing areas is much more expensive than building on green field sites, and despite the now urgent environmental concerns.

For one proposed ecotown site in Oxfordshire, 15,000 new houses had been proposed over currently agricultural or other 'green' land, in which there is even a 'Site of Scientific Interest'(SSI). SSIs are protected nationally because of special features such as geological formations, rare and threatened biodiversity, etc. "They include some of our most spectacular and beautiful habitats - large wetlands teaming with waders and waterfowl, winding chalk rivers, gorse and heather-clad heathlands, flower-rich meadows, windswept shingle beaches and remote upland moorland and peat bog" (http:// www.sssi.naturalengland.org.uk). In this Oxfordshire case, the SSSI status is due to some rare threatened species on rough grassland on a flood plain. In fact, a considerable part of the whole area considered for this proposed ecotown is low-lying flood plain. To an outsider the debate was fascinating, as all the local and many of the national wildlife societies fiercely fought against the choice of this and of several of the other ecotown sites proposed by that Government in association with some large and powerful private developers. That Government's hope that choice of the word 'ecotown' would be politically popular seems to have turned against them, when the ecological credentials were held up to ridicule by so many of the specialists in ecology.

However, again, it is the interpretation of the words that allows this difference of opinion about ecological benefit. Whereas that Government was portraying a narrow ecological objective of reducing carbon emissions in the buildings themselves, others were considering ecological costs and benefits, and especially biodiversity, in their several wider interpretations. In fact, it was too easy for the protestors to ridicule even the carbon reduction ideals for such a development of houses, roads and cars, situated beside an already often jammed motorway, when compared to the current uses of the land growing plants, be they grass, pastures, crops, or protected wilderness as in the SSSI. Furthermore, the building of new housing estates on flood plains has become notorious in recent years with the press coverage of abnormal recent storms causing considerable flooding of homes. Since the dramatic effects of the record rainfall in UK in 2012 and so much flooding, this issue has been dramatically emphasised.

Planning permission was not granted for the specific ecotown in Oxfordshire discussed above. As for biodiversity, well, such an ecotown, if it had been achieved, would certainly increase the human biomass, but this would be an unusual objective for those supporting 'biodiversity'. As well as ruining the protected wildlife areas, the proposed ecotown would 
have ruined acres of food-producing farmland, and we wish again to remind readers that biodiversity is also important in farm stock. Yet, farmers are easily tempted by the great financial rewards of selling their land for housing, when, as farmers, they are struggling financially, partly due to all the bureaucracy of different governmental and EU legislation, and greatly because of the purchasing power of the large supermarket chains, who, in turn, provide such a wide range of foods at affordable prices to all of us.

\section{Conclusion} solely with the conservation of rare species, but to bear in mind that innovation, whether modified by nature or by human action, also may increase biodiversity. Diversity in attitudes to land-use exists, but claims that all or any foster biodiversity should be critically reviewed in relation to time and place, and in relation to the elastic ways in which the term 'biodiversity' is used by different social actors.

31 As regards food and nutrition today, one common factor affecting all three of our examples is the current importance of the large supermarket chains :

- the supermarkets are where the Scots interviewed generally now buy their food, as do the Irish and the English;

- the strong purchasing power of the supermarkets is a big factor in the financial problems of small farmers; and

- inhabitants of any rural settlement, even an ecotown, tend to need a car to reach a supermarket, while car use and roads are a significant issue for the ecologically conscientious.

Furthermore, to emphasise an ecological point, the supermarket buildings and their large car parks sprawl over a great deal of previously green land. On the other hand, it is unarguable that supermarkets and their transport networks have dramatically increased the species diversity on their own fresh and frozen food counters, available to us all throughout the year, but much of that diversity is at the cost of transport from distant places, the so-called 'food miles' issue; surely such transport and its carbon emissions are not ecologically desirable nor probably sustainable.

Meanwhile, it takes an expert to identify the biodiversity in the supermarkets' industrially produced foods, and many of the poorest in our society live off the cheapest, industrially-produced foods - in fact, we suggest that the urban foragers described by Rachel Black (2007) have a more biodiverse diet through scavenging the fresh food waste from markets of all sorts than those living off purchases of the cheapest industrially produced foods. Should not such urban foraging be encouraged rather than stimulate occasional caustic comments in the press?

Our conclusion in 2008 and in 2013 does not extend to proposing any cures, as requested by one questioner in the conference from which this paper emanates. 


\section{BIBLIOGRAPHIE}

Adams J.S. \& McShane T.O. 1996 - The Myth of Wild Africa. Berkeley, University of California.

Black R. 2007 - Eating garbage : socially marginal food provisioning practices. In MacClancy J., Henry J. \& Macbeth H. (Ed.) Consuming the Inedible : neglected dimensions of food choice. Oxford, Berghahn.

Boycott O. 2006 - Vanishing trick for Ireland's second homes. Guardian Newspaper 6 Sep 2006.

Boyle M. 2002 - Cleaning up after the Celtic Tiger : Scalar 'Fixes' in the Political Ecology of Tiger Economies. Transactions of the Institute of British Geographers (N.S.) 27(2) : 172-194.

Budiansky S. 1995 - Nature's Keepers : the new science of nature management. New York, The Free Press.

Collinson P.S. 1999 - Development, Local Politics and the 'New Europe' in County Donegal. Unpublished PhD Thesis, Oxford Brookes University.

Collinson P.S. 2005 - Development, democracy and the New Europe in the Irish Borderlands. In Wilson, T.M. \& Donnan H. (Ed.). Culture and Power at the Edges of the State. Munster, Lit Verlag. Comhar (Sustainable Development Council) 2008 - Biodiversity Forum Briefing Paper. Conserving Ireland's Biodiversity. Dublin : Comhar.

Coyle C. 1994 - Administrative capacity and the implementation of EU environmental policy in Ireland. In Baker S., Milton K. \& Yearly S. Protecting the Periphery. Environmental Policy in Peripheral Regions of the European Union. Newbury Park, Frank Cass.

Cresta M., Grippo F., De Barros D., Vienna A., Carro F., Cataldo R., De Maio M., Positano, L. Santangelo T. \& Tancredi M. 2000 - Politica Alimentare per lo Sviluppo Vallo di Diano. La Rivista di Scienze dell'Alimentazione, 29 (3).

Davies A. 2003 - Waste wars-public attitudes and the politics of place in waste management strategies. Irish Geography 36(1) : 77-92.

Deegan J. \& Dineen D.A. 1997 - Tourism Policy and Performance : The Irish Experience. London, International Thomson Business Press.

Dillon S. 1996 - Vulnerable Landscapes and the Inadequacies of the Irish Planning Acts, Dublin University Law Journal 18 : 102-125.

DKM Economic Consultants 2009 Review of the Construction Industry 2008 and Outlook 2009-2011. Dublin, Department of the Environment, Heritage and Local Government.

González Turmo I. 1998 - Spain : the evolution of habits of consumption 1925-1997, Rivista di Antropologia, Suppl.Vol $76: 335-342$.

Kelly M. 2007 - Environmental Debates and the Public in Ireland. Dublin, Institute of Public Administration.

Kelly M. 2004 - Environmental Attitudes and Behaviours: Ireland in Comparative European Perspective : Third Report of National Survey Data. Dublin, Social Sciences Research Centre, UCD.

Leonard L. 2008 - The Environment Movement in Ireland. Springer, Guildford. 
Macbeth H. 1989 - "Nature/Nurture" - the False Dichotomies, Anthropology Today, 5(4) : 12-15.

Macbeth H. 2006 - The Creation of the New National Parks in Scotland. In Simonič P. (ed.) Ethnography of Protected Areas : endangered habitats - endangered cultures. Ljubljana University of Ljubljana.

Macbeth H. 2007 - Nourritures Sauvages, Gens de Parcs Nationaux en Écosse. In Boëtsch G. \& Hubert A. (Ed.) L'Alimentation en Montagne. Gap, Hautes-Alpes.

Mars G. \& Mars V. 2004 - Doing it wrong : why bother to do imperfect research? In Macbeth H. \& MacClancy J. (Ed.) Researching Food Habits : methods and problems. Oxford, Berghahn.

McDonagh J. 2007 - Rural Development in Ireland - retrospect and prospect. In Bartley B. \& Kitchin R. (Ed.) Understanding Contemporary Ireland. London, Pluto Press.

McDonagh J., Varley T. \& Shortall S. (Ed.) 2009 - A living countryside ? : the politics of sustainable development in rural Ireland. Farnham, Ashgate.

McDonald F \& Nix J. 2006 - Chaos at the Crossroad. Dublin, Gandon,

Motherway B., Kelly M., Faughnan. P. \& Tovey H. 2003 - Trends in Irish Environmental Attitudes between 1993 and 2002. First Report of National Survey Data. Dublin, Environmental Protection Agency.

National Parks (Scotland) Act 2000.

Scottish Natural Heritage 2001a - The Report on the Proposal for the Loch Lomond and the Trossachs National Park : an account of the consultation programme and analysis of responses. Perth, Scotland, Scottish Natural Heritage.

Scottish Natural Heritage 2001b - The Report on the Proposal for a National Park in the Cairngorms : an account of the information received during the consultation exercise. Aberdeen, Scotland, Scottish Natural Heritage.

Taylor G. 1998 - Conserving the Emerald Tiger : the Politics of Environmental Regulation in Ireland, Environmental Politics 7(4) : 53-74.

Tovey H. 2007 - Environmentalism in Ireland. Movement and Activists. Dublin, Institute of Public Administration.

Wickham J. \& Lohan M. 2000 - Dublin's car system. In Slater E. \& Peillon M. (Eds) Memories of the Present. A Sociological Chronology of Ireland 1997-8. Dublin, Institute of Public Administration.

www.ssi.naturalengland.org.uk

\section{RÉSUMÉS}

Fondé sur une approche critique de débats obsolètes sur la prétendue dichotomie naturenourriture, cet article s'intéresse à la façon dont les gens se servent de la finalité de la biodiversité - avec les concepts associés comme la conservation et la durabilité - dans leurs différentes façons de défendre des objectifs variés de gestion du milieu rural. Des situations en Écosse, Irlande et Angleterre sont décrites pour montrer les différentes conceptions de l'usage de la terre et les débats politiques y afférant. L'article a été présenté au 26th Symposium de l'ICAF en décembre 2008 et est fondé sur des données antérieures à cette date. Il a été quelque peu mis à jour en 2013 seulement pour les terrains où la situation a changé de façon significative.

Après avoir souligné la contradiction dans l'expression 'conservation de la nature', l'article avance qu'il ne suffit pas de considérer la biodiversité en termes de conservation d'espèces rares 
ou endémiques, mais aussi de garder à l'esprit que l'innovation accroît également la biodiversité. L'article souligne l'importance des facteurs sociaux dans la façon dont les gens perçoivent la nature et l'environnement, et se comportent vis-à-vis d'eux. L'article conclut entre autres que bien que le terme biodiversité soit beaucoup utilisé dans les arguments opposés par des acteurs du milieu rural et a souvent une signification très large et floue dans les discours populaires, en écologie il a un sens plus précis qui doit être placé dans un contexte géographique et temporel spécifique.

Based on a critical approach to outdated debates about the so-called 'Nature-Nurture' dichotomy, this paper identifies how people use the objective of biodiversity - along with related concepts such as conservation and sustainability - in different ways to defend their pursuit of diverse aims for the management of the countryside. Situations in Scotland, Ireland and England are described to exemplify this in regard to differing conceptions of, and political debates surrounding, the use of land. The paper was presented at the $26^{\text {th }}$ ICAF conference in December 2008 and is based on material prior to that date. It has been briefly updated in 2013 only where a situation has changed significantly.

After identifying the contradiction in the phrase 'nature conservation', the paper argues that it is important not to equate biodiversity solely with the conservation of rare or native species but to bear in mind that innovation also increases biodiversity. The paper draws out the importance of social factors in determining how different people view nature and the environment, and thus their behaviour towards it. An important conclusion of the paper is that although the term biodiversity is much used in opposing arguments about countryside and often has an elastic meaning in popular discourse, in ecology it has a more precise meaning which must be situated in a specific temporal and geographical context.

\section{INDEX}

Index géographique : Angleterre, Écosse, Irlande

Mots-clés : biodiversité, nature, milieu rural, utilisation de la terre, écocité, environnement, conservation, durabilité

Keywords : biodiversity, nature, countryside, land-use debates, ecotowns, Scotland, Ireland, England, environment, conservation, sustainability

\section{AUTEURS}

\section{HELEN MACBETH}

Honorary Research Fellow in Anthropology,

Oxford Brookes University,

Gipsy Lane, Headington,

Oxford,

OX3 OBP, U.K.

hmacbeth@brookes.ac.uk

\section{PAUL COLLINSON}

Research Associate in Anthropology

Oxford Brookes University

Gipsy Lane, Headington,

Oxford, 
OX3 OBP, U.K

paulscollinson@gmail.com 